\title{
Effects of Protein-Sparing Modified Fasting on Obese Japanese Patients
}

\author{
Yasushi SAITo, * Yo IshiKawa, Masaki SHINomiYa, \\ Kohji ShiraI, and Sho Yoshida \\ Second Department of Internal Medicine, School of Medicine, Chiba University, \\ Chiba 280, Japan
}

(Received August 9, 1986)

\begin{abstract}
Summary A protein-sparing modified fasting diet containing $240 \mathrm{kcal}$ per day with supplemental nutrients was used for weight reduction of 15 Japanese patients with obesity. The effects of this treatment on glucose and lipid metabolism, uric acid and hormone levels, and body weight loss were investigated. The rate of body weight reduction was about 500 $\mathrm{g}$ per day in the first week, and $300 \mathrm{~g}$ per day thereafter. The average weight loss after 4 weeks was $12 \%$ of the initial relative weight obtained from standard body weight. Glucose tolerance was improved, and no significant alterations in the measured variables were observed except positive ketonuria, a slight increase in plasma uric acid during the first 2 weeks, and a decrease in the $T_{3}$ level.
\end{abstract}

Key Words: protein-sparing, obesity, Japanese, modified fasting

Obesity is an important risk factor because it can lead to hypertension [1], hyperlipidemia [2], ischemic heart disease [3], atherosclerosis [3], diabetes mellitus [4], and gout [5]. There are many treatments for simple obesity, such as diet, exercise, drugs [6-8] and surgical removal of part of the intestine [9]. Dietary treatments such as semistarvation or total starvation are tried in Western countries to reduce the body weight of obese individuals $[10,11]$. However, serious cardiovascular complications [12] and even death [13] have been observed on administration of liquid-protein diet or total starvation. On the other hand, adequately supplemented semistarvation diets have been recently reported [10, 13]. In Japan, supplemented semistarvation therapy has not been used. Therefore, we performed semistarvation therapy using Modifast ${ }^{\mathrm{R}}$ for Japanese patients with simple obesity, and examined the effects of this treatment on protein and lipid metabolism and hormonal levels. The value of semistarvation therapy for Japanese is discussed.

*To whom correspondence should be addressed. 


\section{SUBJECTS AND METHODS}

Patients and procedure of protein-sparing modified fasting using Modifast. Obesity was defined by a body weight of 120 percent or more of the standard body weight according to Broca's method modified for Japanese by Katsura ( $\{$ height $(\mathrm{cm})-$ $100\} \times 0.9 \mathrm{~kg}$ ) [14]. Six obese males of 13 to 52 years of age with body weights of 141 to 181 percent (mean $163.0 \%$ ) of the standard values and nine obese females of 16 to 47 years of age with body weights of 133 to $210 \%$ (mean $163.4 \%$ ) of the standard values were studied. After confirming the diagnosis of obesity, having excluded secondary obesity, we initiated semistarvation therapy on the patients, all of whom were hospitalized. One adolescent boy (T.Y., 13 years old) had obesity accompanied with Pickwickian syndrome, and thus weight reduction was urgent. One girl (S.N., 16 years old) was already mature and very nervous about her obesity; therefore she was eager to take the semistarvation diet. The patients received instructions from clinical dieticians, and no medication was permitted either before or during the study. Each patient received Modifast in powder form (dissolved in $300 \mathrm{ml}$ of water) three times a day, as well as more than 2.5 liters of water per day.

The dietary treatment consisted of the successive intake of a 1,300 kcal, 1,000 $\mathrm{kcal}$, and $700 \mathrm{kcal}$ regular diet ( 3 days for each); and then the modified proteinsparing diet (Modifast therapy). Control data for values during Modifast therapy were obtained during the first stage of the $1,300 \mathrm{kcal}$ intake.

Composition of Modifast. Three packs of Modifast provided $240 \mathrm{kcal}$ per day and contained a total of $33.0 \mathrm{~g}$ of protein, $0.7 \mathrm{~g}$ of fat, and $25.5 \mathrm{~g}$ of carbohydrate. The contents of vitamins and trace elements in 3 packs of Modifast were as follows: vitamin A, $0.9 \mathrm{mg} ; \mathrm{D}, 2.5 \mu \mathrm{g} ; \mathrm{E}, 12 \mathrm{mg} ; \mathrm{B}_{1}, 16 \mathrm{mg} ; \mathrm{B}_{2}, 20 \mathrm{mg} ; \mathrm{B}_{6}, 1.8 \mathrm{mg}$; C, $75 \mathrm{mg}$; nicotinic acid, $15 \mathrm{mg}$; pantothenic acid, $8 \mathrm{mg}$; folic acid, $0.4 \mathrm{mg}$; sodium, $1.0 \mathrm{~g}$; potassium, $1.0 \mathrm{~g}$; chloride, $0.8 \mathrm{~g}$; calcium, $0.8 \mathrm{~g}$; magnesium, $0.26 \mathrm{~g}$; phosphate, $0.8 \mathrm{~g}$; and iron, $25 \mathrm{mg}$. Modifast was kindly supplied by Wander Co., Netherlands.

Measurements of body weight and blood sampling. Patients were weighed every morning wearing a hospital gown and after voiding urine. Venous blood samples were taken after overnight fasting before the patients got out of bed.

Assay of post-heparin lipolytic activity. Post-heparin plasma was obtained 10 min after injection of $10 \mathrm{U} / \mathrm{kg}$ of heparin into patients. Total lipase activity was measured using tri[1-14C]oleoylglycerol emulsified with Triton X-100 in the presence of $2 \mu \mathrm{g}$ apolipoprotein CII. Released $\left[{ }^{14} \mathrm{C}\right]$ oleic acid was determined as described previously [15]. Hepatic lipase activity was assayed in the presence of $1 \mathrm{M}$ $\mathrm{NaCl}[16]$ and lipoprotein lipase activity was calculated as the difference between the value for total lipase activity and that for hepatic lipase activity.

Clinical laboratory test. Routine clinical laboratory tests were performed in the Central Laboratory of Chiba University Hospital. 
Results are presented as mean $\pm \mathrm{SD}$. Statistical analyses wereper formed using Student's $t$-test for paired data [17].

\section{RESULTS}

Characteristics of the patients studied and their obesity indices are shown in Table 1.

\section{Body weight reduction}

The changes in body weight of the individual subjects during Modifast therapy are shown as changes in the obesity index in Fig. 1. All the patients lost weight. The mean obesity index just before Modifast therapy was $163 \pm 24 \%$, and the indices at weeks 2,4 , and 6 were $153 \pm 23,151 \pm 20$, and $146 \pm 23 \%$, respectively. Figure 2 shows the time course of average body weight reductions per day. The reduction was about $500 \mathrm{~g} /$ day in the first week of therapy and then about $300 \mathrm{~g} /$ day.

\section{Glucose metabolism}

Table 2 shows results on glucose metabolism just before and after Modifast therapy for at least 6 weeks. The fasting plasma glucose levels tended to decrease

Table 1. Data on obese patients.

\begin{tabular}{lccccc}
\hline Name & Sex & $\begin{array}{c}\text { Age } \\
(\text { years })\end{array}$ & $\begin{array}{c}\text { Height } \\
(\mathrm{cm})\end{array}$ & $\begin{array}{c}\text { Body weight } \\
(\mathrm{kg})\end{array}$ & $\begin{array}{c}\text { Obesity index } \\
(\%)\end{array}$ \\
\hline T.Y. & $\mathrm{M}$ & 13 & 157 & 94 & 181 \\
F.K. & $\mathrm{M}$ & 21 & 166 & 89 & 153 \\
M.M. & $\mathrm{M}$ & 32 & 157 & 86 & 170 \\
A.T. & $\mathrm{M}$ & 37 & 160 & 88 & 164 \\
K.Y. & $\mathrm{M}$ & 48 & 166 & 99 & 169 \\
S.H. & $\mathrm{M}$ & 52 & 161 & 77 & 141 \\
S.N. & $\mathrm{F}$ & 16 & 163 & 78 & 137 \\
T.H. & $\mathrm{F}$ & 19 & 157 & 83 & 162 \\
W.K. & $\mathrm{F}$ & 22 & 155 & 94 & 189 \\
H.S. & $\mathrm{F}$ & 23 & 157 & 97 & 193 \\
K.K. & $\mathrm{F}$ & 23 & 143 & 69 & 161 \\
N.T. & $\mathrm{F}$ & 23 & 165 & 128 & 210 \\
S.S. & $\mathrm{F}$ & 33 & 161 & 82 & 149 \\
S.M. & $\mathrm{F}$ & 43 & 155 & 68 & 138 \\
H.T. & $\mathrm{F}$ & 47 & 158 & 69 & $163.0 \pm 14.1$ \\
\hline Average & $\mathrm{M}=6$ & $34 \pm 11$ & $161.2 \pm 4.1$ & $88.8 \pm 7.5$ & $163.5 \pm 27.8$ \\
\hline Total & $\mathrm{F}=9$ & $28 \pm 11$ & $157.4 \pm 6.9$ & $85.3 \pm 19.1$ & $163.4 \pm 24.0$ \\
\hline
\end{tabular}

The Obesity index is the body weight as a percentage of the standard body weight. The standard body weight was calculated by the modified method of Broca [14] for Japanese (Katsura's method, \{height $(\mathrm{cm})-100\} \times 0.9(\mathrm{~kg})$ ). 


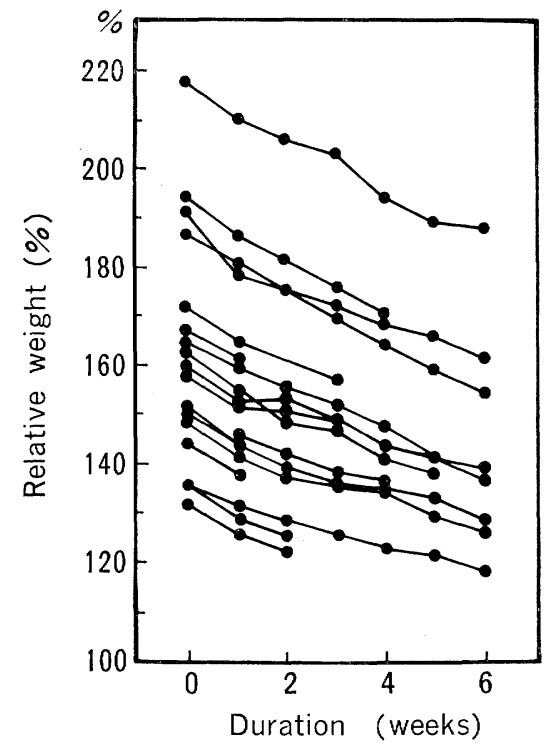

Fig. 1. Effect of Modifast therapy on relative body weight.

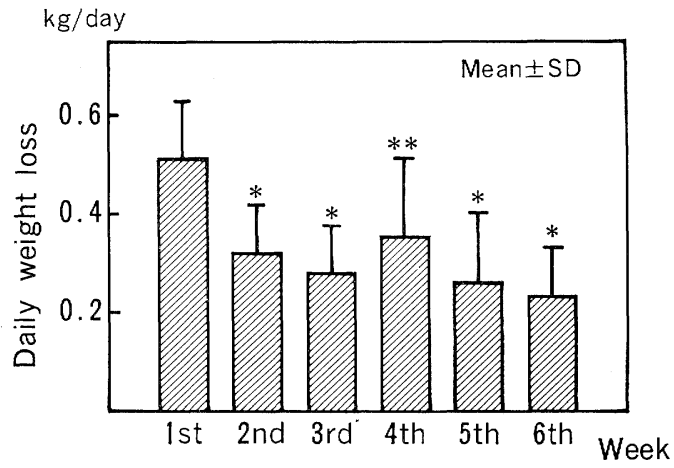

Fig. 2. Average daily weight loss during Modifast therapy. Daily weight losses during weeks 2-6 were significantly lower than those during the significantly different from the value during week $1 . * p<0.001 ; * * p<0.02$.

during therapy, but remained in within the normal range. C-Peptide excretion also decreased (Table 2-A), being significantly lower by the 6th week. Results of glucose tolerance tests are shown in Table 2-B. Glucose intolerance, observed initially, improved greatly during treatment. Immunoreactive insulin (IRI) secretion was decreased by the treatment, but the $\Delta \mathrm{IRI} / \Delta$ glucose ratio [18] at $30 \mathrm{~min}$. ( $\Delta \mathrm{IRI}=$ IRI at $30 \mathrm{~min}-$ IRI initially, $\Delta$ glucose = plasma glucose at $30 \mathrm{~min}$-plasma glucose initially) remained unchanged ( 0.89 before and 0.91 after treatment). 
Table 2. Glucose metabolism during Modifast therapy.

(A) Fasting plasma glucose levels and urinary C-peptide concentrations during protein sparing, modified fasting.

\begin{tabular}{lcccl}
\hline \multicolumn{1}{c}{ Week } & 0 & 2 & 4 & 6 \\
\hline Fasting plasma glucose $(\mathrm{mg} / \mathrm{dl})$ & $89 \pm 17$ & $78 \pm 13$ & $74 \pm 9$ & $77 \pm 7$ \\
Urine C-peptide $(\mu \mathrm{g} /$ day) & $55 \pm 21$ & - & - & $33 \pm 25^{*}$ \\
\hline
\end{tabular}

${ }^{*} p<0.02$ compared with value at week 0 .

(B) Oral glucose tolerance test $(75 \mathrm{~g})$ during protein sparing, modified fasting.

\begin{tabular}{clcc}
\hline \multirow{2}{*}{ Min } & & \multicolumn{2}{c}{ Modifast therapy } \\
\cline { 3 - 4 } & & Before & After \\
\hline 0 & Plasma glucose & $107 \pm 35$ & $75 \pm 11^{* *}$ \\
& IRI $^{\mathrm{a}}$ & $16 \pm 7$ & $10 \pm 4$ \\
30 & Plasma glucose & $172 \pm 55$ & $112 \pm 32^{* * *}$ \\
& IRI & $74 \pm 43$ & $44 \pm 19$ \\
60 & Plasma glucose & $194 \pm 103$ & $119 \pm 46^{*}$ \\
& IRI & $64 \pm 37$ & $40 \pm 18$ \\
90 & Plasma glucose & $194 \pm 94$ & $118 \pm 61^{*}$ \\
& IRI & $76 \pm 35$ & $37 \pm 9$ \\
& Plasma glucose & $196 \pm 92$ & $117 \pm 50^{*}$ \\
& IRI & $79 \pm 31$ & $35 \pm 8^{* *}$ \\
\hline
\end{tabular}

Mean $\pm \mathrm{SD}(n=6) ;{ }^{\mathrm{a}} \mathrm{mg} / \mathrm{dl} ;{ }^{\mathrm{b}} \mu \mathrm{U} / \mathrm{ml} .{ }^{*} p<0.05 ;{ }^{*} p<0.02 ; * * * p<0.01$.

\section{Lipid metabolism}

Table 3 shows changes in serum lipids. The levels of total cholesterol, lowdensity lipoprotein (LDL)-cholesterol, and high-density lipoprotein (HDL)-cholesterol tended to decrease during therapy, but the decreases were not significant. Very low density lipoprotein (VLDL)-triglyceride also decreased. The level of free fatty acids increased from week 2 to 6 . The activities of lipoprotein lipase (LpL) and hepatic triglyceride lipase (HTGL) in postheparin plasma were high before Modifast therapy (LpL, $4.8 \pm 2.9 \mu \mathrm{mol} / \mathrm{ml} / \mathrm{h}, \mathrm{HTGL}, 10.4 \pm 6.2 \mu \mathrm{mol} / \mathrm{ml} / \mathrm{h}$ ) and both activities decreased to almost normal levels during treatment.

\section{Hormonal changes accompanying Modifast therapy}

Results on plasma and urinary hormone concentrations are shown in Table 4. Modifast therapy decreased the $T_{3}$ level to below normal. Increase in reverse $T_{3}\left(\mathrm{rT}_{3}\right)$ and free $T_{4}$ were observed, but were not significant. The $T_{4}$ level decreased, but also not significantly. Other hormones remained within normal ranges.

\section{Routine examinations}

Table 5 shows hematological and biochemical data obtained from routine examinations during Modifast therapy. Values were within the normal ranges, except the uric acid level, which increased significantly at weeks 2 and 4 of therapy, 
Table 3. Effect of Modifast therapy on plasma lipid and post-heparin lipolytic activities.

\begin{tabular}{lcccc}
\hline \multicolumn{1}{c}{ Weeks } & 0 & 2 & 4 & 6 \\
\hline Total cholesterol $(\mathrm{mg} / \mathrm{dl})$ & $203 \pm 46$ & $183 \pm 45$ & $164 \pm 23^{*}$ & $182 \pm 33$ \\
LDL-Cholesterol $(\mathrm{mg} / \mathrm{dl})$ & $141 \pm 35$ & $127 \pm 31$ & $115 \pm 28$ & $126 \pm 9$ \\
HDL-Cholesterol $(\mathrm{mg} / \mathrm{dl})$ & $42 \pm 9$ & $37 \pm 5$ & $38 \pm 7$ & $36 \pm 6$ \\
Triglyceride $(\mathrm{TG})(\mathrm{mg} / \mathrm{dl})$ & $102 \pm 40$ & $89 \pm 22$ & $91 \pm 18$ & $90 \pm 18$ \\
VLDL-TG $(\mathrm{mg} / \mathrm{dl})$ & $81 \pm 35$ & $68 \pm 14$ & $46 \pm 14$ & $51 \pm 15$ \\
FFA $(\mu \mathrm{Eq} / \mathrm{liter})$ & $1,069 \pm 436$ & $1,224 \pm 343$ & $1,498 \pm 695$ & $1,402 \pm 115$ \\
\hline LpL $(\mu \mathrm{mol} / \mathrm{ml} / \mathrm{h})$ & $4.8 \pm 2.9$ & - & - & $2.9 \pm 1.0^{*}$ \\
HTGL $(\mu \mathrm{mol} / \mathrm{ml} / \mathrm{h})$ & $10.4 \pm 4.2$ & - & - & $4.6 \pm 3.0^{*}$ \\
\hline
\end{tabular}

Values are Mean \pm SD. Normal range: LpL; $3.4 \pm 1.6 \mu \mathrm{mol} / \mathrm{ml} / \mathrm{h} ;$ HTGL, $5.5 \pm 1.1 \mu \mathrm{mol} / \mathrm{ml} / \mathrm{h}$. ${ }^{*} p<0.01$ compared with value at week 0 .

Table 4. Effect of Modifast therapy on hormone levels and routine laboratory data on plasma and urine.

\begin{tabular}{llcc} 
& & \multicolumn{2}{c}{ Modifast therapy } \\
\cline { 3 - 4 } & Normal range & Before & After \\
\hline Adrenaline (urine) & $3.0-15.0 \mu \mathrm{g} /$ day & $6.1 \pm 3.3$ & $9.3 \pm 1.7$ \\
Noradrenaline (urine) & $26-121 \mu \mathrm{g} /$ day & $70.6 \pm 20.0$ & $57.4 \pm 9.2$ \\
Plasma cortisol & $4.5-20 \mu \mathrm{g} / \mathrm{dl}$ & $9.3 \pm 3.2$ & $13.9 \pm 6.2$ \\
17 OHCS (urine) & $2.4-6.4 \mathrm{mg} /$ day & $7.4 \pm 2.6$ & $6.7 \pm 1.9$ \\
17 KS (urine) & $3.0-8.0 \mathrm{mg} / \mathrm{day}$ & $6.4 \pm 0.5$ & $3.7 \pm 2.2$ \\
GH & $<5 \mathrm{ng} / \mathrm{ml}$ & $2.9 \pm 1.6$ & $3.3 \pm 3.5$ \\
TSH & $<5 \mu \mathrm{U} / \mathrm{ml}$ & $1.4 \pm 0.3$ & $1.3 \pm 0.3$ \\
Somatomedin-C & $0.64-2.22 \mathrm{U} / \mathrm{ml}$ & $0.80 \pm 0.44$ & $0.80 \pm 0.35$ \\
Glucagon & $40-180 \mathrm{pg} / \mathrm{ml}$ & $81 \pm 48$ & $55 \pm 20$ \\
$\mathrm{~T}_{3}$ & $1.1-2.25 \mathrm{ng} / \mathrm{ml}$ & $1.11 \pm 0.39$ & $0.77 \pm 0.37^{*}$ \\
$\mathrm{~T}_{4}$ & $4.5-12.0 \mu \mathrm{g} / \mathrm{dl}$ & $7.09 \pm 2.00$ & $5.23 \pm 0.68$ \\
Free $\mathrm{T}_{4}$ & $0.80-2.30 \mathrm{U} / \mathrm{ml}$ & $1.25 \pm 0.20$ & $1.56 \pm 0.38$ \\
Reverse $\mathrm{T}_{3}$ & $190-375 \mathrm{pg} / \mathrm{ml}$ & $378 \pm 43$ & $566 \pm 343$ \\
TBG & $15-28 \mathrm{ng} / \mathrm{ml}$ & $21.5 \pm 4.6$ & $16.3 \pm 5.7$ \\
\hline
\end{tabular}

17OHCS, 17-hydroxycortisol; 17KS, 17-ketosteroid; GH, growth hormone; TSH, thyroidstimulating hormone; TBG, thyroid-binding globulin. ${ }^{*} p<0.01$.

but returned to the pre-therapy level by week 6. As shown in Fig. 3(a), urinary uric acid excretion per day decreased when the amount of urinary ketone bodies was increased; and as shown in Fig. 3(b), the plasma uric acid level was inversely correlated with urinary uric acid excretion.

\section{DISCUSSION}

Semistarvation therapy has been used for treatment of morbid obesity in Europe and the United States [10, 11]. In Japan, such therapy had not been evaluated here to fore, primarily because the incidence and grade of obesity have been less in Japan than in Western countries. But recently, the incidence of obesity 
Table 5. Laboratory findings.

\begin{tabular}{llcccc}
\hline & Normal range & 0 & 2 & 4 & 6 weeks \\
\hline Hemoglobin & $12-18 \mathrm{~g} / \mathrm{dl}$ & $14.2 \pm 1.5$ & $14.3 \pm 2.0$ & $14.1 \pm 1.7$ & $12.9 \pm 1.4^{*}$ \\
WBC & $4,000-9,000 / \mathrm{mm}^{3}$ & $5,200 \pm 1,600$ & $5,600 \pm 1,500$ & $4,800 \pm 1,600$ & $3,700 \pm 800^{* *}$ \\
RBC & $375-500 \times 10^{4}$ & $478 \pm 60$ & $482 \pm 61$ & $468 \pm 69$ & $435 \pm 71^{*}$ \\
Platelets & $12-35 \times 10^{3} / \mathrm{mm}^{3}$ & $22.1 \pm 5.0$ & $22.7 \pm 2.7$ & $20.1 \pm 4.6$ & $18.4 \pm 5.9$ \\
Total protein & $6.5-8.2 \mathrm{~g} / \mathrm{dl}$ & $7.3 \pm 0.6$ & $7.3 \pm 0.5$ & $7.1 \pm 0.5^{*}$ & $6.8 \pm 0.5^{* *}$ \\
BUN & $10-20 \mathrm{mg} / \mathrm{dl}$ & $12 \pm 3.5$ & $11.9 \pm 4.3$ & $9.4 \pm 2.1$ & $9.6 \pm 4.1$ \\
Uric acid & $2.5-8.0 \mathrm{mg} / \mathrm{dl}$ & $6.6 \pm 1.7$ & $8.9 \pm 2.4^{*}$ & $7.7 \pm 1.2$ & $6.8 \pm 0.6$ \\
Na & $135-145 \mathrm{mEq} /$ liter & $139 \pm 2.5$ & $138 \pm 1.2$ & $139 \pm 1.6$ & $139 \pm 2.2$ \\
K & $3.6-5.0 \mathrm{mEq} / \mathrm{liter}$ & $4.3 \pm 0.2$ & $4.1 \pm 0.6$ & $4.3 \pm 0.6$ & $4.0 \pm 0.3$ \\
GOT & $7-40 \mathrm{mU} / \mathrm{ml}$ & $36 \pm 19$ & $38 \pm 15$ & $47 \pm 30$ & $44 \pm 20$ \\
GPT & $7-40 \mathrm{mU} / \mathrm{ml}$ & $46 \pm 36$ & $43 \pm 26$ & $51 \pm 38$ & $49 \pm 36$ \\
Ch-E & $2.0-6.0 \times 10^{3} \mathrm{IU} /$ liter & $5.8 \pm 1.5$ & $5.6 \pm 1.1$ & $4.7 \pm 1.1^{* *}$ & $4.7 \pm 1.4^{* *}$ \\
\hline
\end{tabular}

Mean \pm SD. BUN, Blood urea nitrogen; Ch-E, choline esterase. $* p<0.05$ compared with value at week $0 ; * * p<0.01$ compared with value at week 0 .

among Japanese has been increasing because of westernization of the diet [19]. Therefore, an increased need for this type of therapy has resulted. Semistarvation therapy using Modifast for patients with simple obesity was effective in our hospital for reducing body weight (Fig. 1). The body weight decreased $500 \mathrm{~g}$ per day in the first one week and then $300 \mathrm{~g}$ per day in the following weeks. The effectiveness of this treatment was almost the same as that reported from Europe [10, 11, 20]. Two adolescent patients were included in this therapy, and its effect on their body weight was the same as in adults. Merritt et al. [20, 21] reported that obese adolescents treated with the protein-sparing, modified fasting demonstrated its clinical efficacy and minimum side effects as determined by standard biochemical determination [21]. Adequate semistarvation is considered to be safe and effective for the treatment of childhood or adolescent obesity.

Glucose intolerance was observed before treatment, but improved during treatment. After semistarvation, insulin secretion decreased (Table 2), but the $\Delta$ IRI/ $\Delta$ glucose insulin index at $30 \mathrm{~min}$ [18] which is thought to indicate the responsiveness of insulin secretion from $\beta$-cells, was unchanged. These results suggest that the effectiveness of insulin was improved by semistarvation therapy.

The FFA level was increased during treatment, suggesting that lipid mobilization from adipose tissue was enhanced. The post-heparin LpL and HTGL activities of the patients were initially higher than those of control subjects, but decreased to almost the normal ranges during Modifast therapy. These results are consistent with the idea that the adipose tissue mass was reduced. These phenomena might be a reflection of a decrease in insulin over-secretion, because lipoprotein lipase production is known to depend on insulin [22].

The levels of all hormones examined except thyroid hormones remained within normal ranges during therapy (Table 4). As for thyroid hormones, a decrease in the $T_{3}$ level and increase in $r T_{3}$ and free $T_{4}$ were observed. The $T_{3}$ concentration is reported to be affected by the nutritional status [23]. Kaptein et al. [24] reported 

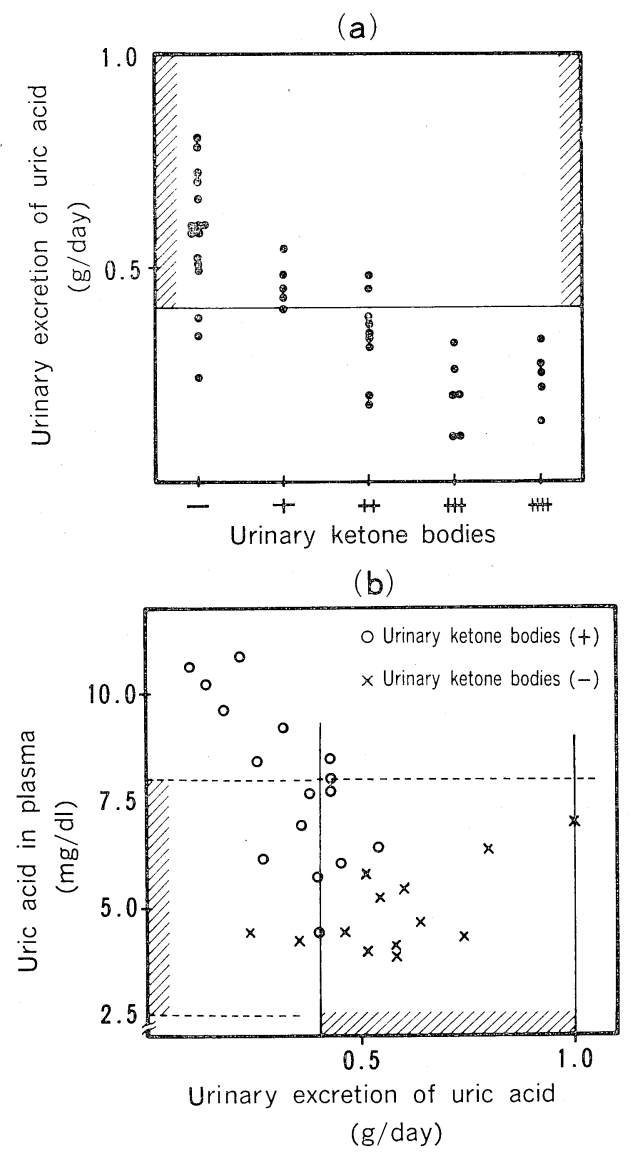

Fig. 3. (a) Relationship between urinary excretion of uric acid and urinary ketone bodies. Amounts of urinary ketone bodies are shown as follows:,$+ 15 \mathrm{mg} / \mathrm{dl} ;++, 40 \mathrm{mg} / \mathrm{dl}$; ,$+++ 80 \mathrm{mg} / \mathrm{dl}$;,$++++ 160 \mathrm{mg} / \mathrm{dl}$. Urinary ketone bodies were measured every morning before patients received Modifast. The hatched area indicates the normal range (mean $\pm 2 \times \mathrm{SD}$ ). (b) Correlation between uric acid in plasma and urinary excretion of uric acid in the presence and absence of urine ketone bodies. The hatched area indicates the normal range (mean $\pm 2 \times \mathrm{SD}$ ).

an increase in $\mathrm{rT}_{3}$ and free $T_{4}$ and a reduction in the $T_{3}$ concentration during protein-supplemented weight reduction. And they speculated that those changes may facilitate conservation of visceral protein and reduce muscle protein turnover. The variation in magnitude of those changes was thought to depend on individual differences in nitrogen economy. No clinical signs or symptoms indicating thyroid functional abnormality were observed.

In routine laboratory examinations, the WBC count at the end of week 6 was below the normal range, but returned to the normal range following the change to an ordinary diet. 
Uric acid was increased in the first two weeks, as previously reported by others [25]. As shown in Fig. 3(a), urinary uric acid secretion was decreased when urinary excretion of ketone bodies increased during semistarvation. Furthermore, an increase in plasma uric acid was observed when uric acid excretion was decreased, suggesting that increase in the former during semistarvation might be partly due to decreased excretion of uric acid. These results also suggest that ketone bodies might directly inhibit the excretion of uric acid from the kidney, which is consistent with Drenick's observation [26]. The excessive accumulation of uric acid is thought to result from accelerated protein breakdown during the initial period of fasting [27] and from impairment of renal uric acid clearance [28, 29]. Aside from the evaluation in uric acid level, the Modifast diet gives a protein intake below the recommended dietary allowance (RDA) level and thus will invariably lead to unnecessary loss of lean tissue. Therefore diet formulae containing higher level of protein are needed to solve these problems.

The Japanese diet is different from that in Europe, especially in salt content, taste, and protein composition. So, the intake of the Modifast is not so familiar but can be tolerated by the Japanese. But in order for the protein-sparing modified fasting to become more familiar and to be widely acceptable for the Japanese, improvement in taste will be required.

Overall, semistarvation therapy using Modifast for obese Japanese was effective almost to the same extent as for European, and showed no serious side effects except minor subjective complaints.

Further studies are now in progress on the value of Modifast therapy.

\section{REFERENCES}

1. Reisin, E. (1983): Obesity and hypertension, in Handbook of Hypertension, ed. by Robertson, J.I.S., Elsevier Science Publishers B.V., Amsterdam, Vol. 1, pp. 30-43.

2. Berchtold, P., Berger, M., Joregens, V., Daweke, C., Chantelan, E., Gries, F.A., and Eimmermann, H. (1981): Cardiovascular risk factors and HDL-cholesterol levels in obesity. Int. J. Obes., 5, 1-10.

3. Hubert, H.B., Feinlieb, M., McNamara, P.M., and Castelli, W.P. (1983): Obesity as an independent risk factor for cardiovascular disease: a 26 year follow up of participants in the Framingham heart study. Circulation, 67, 968-977.

4. West, K.M. (1978): Epidemiology of Diabetes and Its Vascular Lesions, Elsevier, New YorkOxford, pp. 231-248.

5. Shapiro, J.R., Klineberg, J.R., Peck, W., Goldfinger, S.E., and Seegmiller, J.E. (1970): Hyperuricemia associated with obesity and intensified by caloric restriction. Arthritis Rheum. Dis., 29, 553-555.

6. Bloom, W.L. (1959): Fasting as an introduction to the treatment of obesity. Metabolism, 8, 214-224.

7. Horton, E.S. (1973): The role of exercise in the prevension and treatment of obesity, in Obesity in Perspective, ed. by Bray, G.A., Washington DHEW Pub. No. 75-708, Vol. 2, Part 1, pp. 62-66.

8. Cawthorne, M.A., and Arch, J.R.S. (1982): The search for peripherally acting drugs for the treatment of obesity-a review. Int. J. Obes., 6, 1-10. 
9. Mason, E.E. (1982): Vertical banded gastroplasty for obesity. Arch. Surg., 117, 701-708.

10. Coronas, R., Duran, S., Gomez, P., Romero, H., and Sastre, A. (1982): Modified total fasting and obesity: results of a multicentric study. Int. J. Obes., 6, 463-471.

11. Iselin, H.U., and Burckhardt, P. (1982): Balanced hypocaloric diet versus protein-sparing modified fast in the treatment of obesity: a comparative study. Int. J. Obes., 6, 175-181.

12. Lantigua, R.A., Amatruda, J.M., Biddle, T.L., Forbes, G.B., and Lockwood, D.H. (1980); Cardiac arrhythmias associated with a liquid protein diet for the treatment of obesity. $N$. Engl. J. Med., 303, 735-738.

13. Isner, J.M., Sours, H.E., Paris, A.L., Ferraus, V.J., and Roberts, W.C. (1979): Sudden, unexpected death in avid dieters using the liquid-protein-modified fast diet. Circulation, $\mathbf{6 0}$, 1401-1412.

14. Zollnen, N. (1957): Thannhausers Lehrbuch des Stoffwechsels und der Stoffwechselkrankheiten, Thieme Verlag, Stuttgart, p. 57.

15. Matsuoka, N., Shirai, K., and Jackson, R.L. (1980): Preparation and properties of immobilized lipoprotein lipase. Biochim. Biophys. Acta, 620, 308-316.

16. Fredrickson, D.S., Ono, K., and Davis, L.L. (1963): Lipolytic activity of post-heparin plasma in hyperglyceridemia. J. Lipid Res., 4, 24-33.

17. Snedecor, G.W., and Cochhan, W.G. (1967): Statistical Methods (6th ed.), Iowa State University, Ames, Iowa, pp. 91-119.

18. Kosaka, K., Hagura, R., and Kuzuya, T. (1977): Insulin responses in equivocal and definite diabetes, with special reference to subjects who had mild glucose intolerance but later developed definite diabetes. Diabetes, 26, 944-949.

19. Goto, Y., and Abe, R. (1983): Epidemiology of obesity. Saishin Igaku, 38, 288-294 (in Japanese)

20. Merritt, R.J., Bistian, B.R., Blackburn, G.L., and Suskind, R.M. (1980): Consequences of modified fasting in obese pediatric and adolescent patients. I. Protein-sparing modified fast. J. Pediatr., 46, 13-19.

21. Merritt, R.J. (1978): Treatment of pediatric and adolescent obesity. Int. J. Obes., 2, 203-211.

22. Nikkila, E.A. (1983): Familial lipoprotein lipase deficiency and related disorders of chylomicron metabolism, in The Metabolic Basis of Inherited Disease (Vth ed.), ed. by Stanbury, J.B., Wyngaarden, J.B., Fredrickson, D.S., Goldstein, J.L., Brown, M.S., McGraw-Hill Book Co., New York, pp. 622-642.

23. Visser, T.J., Lamberts, S.W.J., Wilson, J.H.P., Doctor, R., and Hennemann, G. (1978): Serum thyroid hormone levels during prolonged reduction of dietary intake. Metabolism, 27, 405-409.

24. Kaptein, E.M., Fisler, J.S., Duda, M.J., Nicloff, J.T., and Drenick, E.J. (1985): Relationship between the changes in serum thyroid hormone levels and protein status during prolonged protein supplemented caloric deprivation. Clin. Endocrinol., 22, 1-15.

25. Cristofori, F.C., and Duncan, G.C. (1964): Uric acid excretion in obese subjects during periods of total fasting. Metabolism, 13, 301-311.

26. Drenick, E.J., Fisler, J.L., and Dennin, H.F. (1971): The effect of allopurinol on the hyperuricemia of fasting. Clin. Pharmacol. Ther., 12, 68-72.

27. Rundles, R.W., Metz, E.N., and Siberman, H.R. (1966): Allopurinol in the treatment of gout. Ann. Intern. Med., 64, 229-258.

28. Goldfinger, S., Klinenberg, J.R., and Seegmiller, J.E. (1955): Renal retension of uric acid induced by infusion of beta-hydroxybutyrate and acetoacetate. N. Engl. J. Med., 272, 351355.

29. Lecocq, F.R., and McPhaul, J.T. (1965): The effects of starvation, high fat diets and ketone infusion on uric acid balance. Metabolism, 14, 186-197. 